\title{
THE CONCEPT OF TECHNICAL LITERACY, AS PERCEIVED BY STUDENTS OF PRIMARY SCHOOL TEACHING STUDENTS AND BY PRIMARY SCHOOL TEACHERS
}

\author{
Eva ROUČOVÁ
}

\begin{abstract}
The article presents selected theoretical definitions of technical literacy, featured in scientific literature, followed by an analysis of the results, based on a research of the subjective perception of the term technical literacy by primary school teaching students and primary school teachers. The article includes the identified basic types of characteristics of perceiving the technical literacy by the respondents.
\end{abstract}

Key words: technical literacy, pedagogical research, student of teaching for primary school, primary school teacher

\section{VNÍMÁNÍ POJMU TECHNICKÁ GRAMOTNOST U STUDENTŮ UČITELSTVÍ PRO PRIMÁRNÍ ŠKOLU A UČITELŮ NA PRIMÁRNÍ ŠKOLE}

Resumé: Článek prezentuje vybraná teoretická vymezení technické gramotnosti v odborné literatuře. V další části jsou analyzovány výsledky výzkumu subjektivního vnímání pojmu technická gramotnost u studentů učitelství a učitelů na primární škole. Obsaženy jsou zjištěné základní typy charakteristik vnímání technické gramotnosti respondenty výzkumu.

Klíčová slova: technická gramotnost, pedagogický výzkum, student učitelství pro primární školu, učitel na primární škole

\section{1 Úvod}

Sféra techniky je jednou z oblastí lidské činnosti, která vykazuje velmi dynamické změny a velký a kontinuální nárůst informací, jejichž platnost bývá často navíc, mnohdy drasticky, časově omezená. $\mathrm{Z}$ těchto důvodů klade současná společnost vysoké nároky na základní technickou gramotnost člověka, jeho prrizpůsobivost a ochotu se celoživotně vzdělávat.

Technická gramotnost je pojem, jehož obecná obsahová náplň se v odborné vzdělávací veřejnosti $\mathrm{v}$ posledních desetiletích intenzivně konstituuje. Výsledky snah o konkrétnější vymezení pojmu lze postihnout především těmito obsahovými aspekty: základní orientace $\mathrm{v}$ různých odvětvích techniky; znalost dějin techniky; znalost podstaty, funkce a konstrukce technického objektu; znalost použitých technologií a materiálů; ekologické, ekonomické, estetické a bezpečnostní informace; znalost a schopnost manipulace $s$ informacemi, které jsou uloženy v elektronické podobě a dalšími.

$S$ podrobnějšími teoretickými analýzami technické gramotnosti je možno se seznámit např́íklad $\mathrm{u}$ následujících teoretiků technického vzdělávání. Kropáč, J. (1, s. 65-66) zdůrazňuje, že: „vymezování pojmu technická gramotnost by mělo zahrnovat složku vědomostní, dovednostní a postojovou" a dále upozorňuje na rozšířený zjednodušený model technické gramotnosti, jako:,technického vzdělanostního minima, které by si měl osvojit každý jedinec." Dyrenfurth, M. (In 1, s. 65) vymezuje technickou gramotnost jako: „souhrn způsobilostí, zahrnující uvědomování si klíčových procesů $\mathrm{v}$ technice, způsobilost obsluhovat technické prístroje a zařízení, způsobilost rozvíjet vlastní technické vědomosti, dovednosti a návyky, způsobilost využívat technické informace a hodnotit je."

Zajímavé kontextově dokreslující výzkumné sdělení poskytuje právě $\mathrm{k}$ tématu technické gramotnosti Almäki, A. (2, s. 7 - 9). Respondenti, učitelé techniky na finských základních školách, byli vyzváni, aby se pokusili o vlastní definici pojmu technická gramotnost. V jejich pojetí zahrnuje technická gramotnost tř́ dimenze: využití techniky, hodnocení techniky a význam techniky. Jednotlivé dimenze vymezují následujícím způsobem ( 2, s. 9 , překlad Roučová, E. 2007):

- Využití techniky zahrnuje získání znalostí a dovedností nutných $\mathrm{k}$ vytváření technických produktů a jejich následné správné používání. 
- Hodnocení techniky spočívá ve schopnosti kritického posouzení dopadu a důsledků techniky.

- Význam techniky spočívá v pochopení výsledků technických inovací a jejich vztahu k vyšší životní úrovni společnosti.

V návaznosti na procesy konstituování a vymezování pojmu technická gramotnost probíhají současně i procesy konstituování a teoretického vymezení dalších souvisejících pojmů, jako např́klad technického myšlení, technické tvořivosti, uživatelství techniky a dalších (3).

Současně s výše uvedenými intenzivními snahami o aktuální teoretické vymezení pojmu technická gramotnost je rozhodně potřeba věnovat větší pozornost výzkumům, které se zaměří na zjištění konkrétní podoby technické gramotnosti u různých skupin školní populace. Výsledky těchto výzkumů se stanou později podkladem pro rozvoj nových a efektivních strategií výuky technických disciplín a především nutným výchozím podkladem $\mathrm{k}$ efektivnímu řízení aktivního učebního procesu, který k optimální podobě technické gramotnosti směřuje.

V následujícím textu popsaný výzkum teoreticky empiricky navazuje na předchozi rozsáhlý výzkum prekonceptů $\mathrm{k}$ technické výchově $(4,6)$ a zahrnoval celou škálu zkoumaných odborných pojmů, přičemž zde jsou prezentovány výsledky pouze pro pojem technická gramotnost.

\section{Použité výzkumné metody}

Pro výzkum, při zpracování dat a při testování platnosti hypotéz byly použity následující metody:

- Metoda teoretické analýzy odborné literatury.

- Metoda sběru a tř́íění dat.

- Metoda pětibodového sémantického diferenciálu pro měření individuálních, psychologických významů pojmu technická gramotnost u jednotlivých osob (5, s. 121).

- Dotazník s pětibodovou škálou sémantického diferenciálu

- -Nestandardizovaný U-test Manna a Whitneyho pro rozhodnutí, zda dva výběry mají zhruba stejné rozdělení četností a mohou tedy pocházet ze stejného základního souboru (5, s. 121).

- Metoda shlukové analýzy pro možnost přiřadit jednotky analýzy (osoby, př́ípady) na základě podobnosti ke skupinám, shlukủm (5, s. 176).

\section{Průběh a výsledky výzkumu \\ Cíl výzkumu}

Hlavním cílem provedeného a zde prezentovaného orientačního výzkumu bylo především zjistit, jaké je subjektivní vnímání pojmu technická gramotnost $\mathrm{u}$ učitelů $\mathrm{z}$ praxe na 1. stupni ZŠ a u studentů učitelství pro primární školu na pedagogické fakultě a do jaké míry se může jejich vnímání podobat, nebo odlišovat.

\section{Otázky výzkumu}

Výzkum byl zaměřen na celou řadu otázek, pro účely tohoto textu jsou podstatné následující problémy:

I. Jak spolu souvisí vnímání pojmu technická gramotnost mezi učiteli v praxi na 1. stupni ZŠ a studenty pedagogické fakulty?

II. Do jaké míry se liší vnímání pojmu technická gramotnost u učitelů na 1. stupni ZŠ a studentů pedagogické fakulty?

III. Jaká základní charakteristika vnímání pojmu technická gramotnost u obou skupin respondentů převažuje?

IV. Jakou důležitost zkoumanému pojmu technická gramotnost obě skupiny respondentů přisoudí?

Hypotézy výzkumu a jejich teoretické zdůvodnění

$\mathrm{Na}$ základě teoretických analýz a pro účely tohoto článku byly stanoveny a vybrány následující hypotézy:

$\mathbf{H}_{1}$ - U vnímání pojmu technická gramotnost je mezi učiteli na 1 . stupni $Z \check{S}$ a studenty pedagogické fakulty významný rozdíl.

$\mathbf{H}_{2}$ U vnímání pojmu technická gramotnost je ve faktoru hodnocení rozdíl mezi učiteli na 1. stupni ZŠ a studenty pedagogické fakulty.

$\mathbf{H}_{3}$ U vnímání pojmu technická gramotnost je ve faktoru aktivity rozdíl mezi učiteli na 1 . stupni ZŠ a studenty pedagogické fakulty.

$\mathbf{H}_{4} \mathrm{U}$ vnímání pojmu technická gramotnost je ve faktoru potence rozdíl mezi učiteli na 1. stupni ZŠ a studenty pedagogické fakulty.

Při teoretickém zdůvodnění formulací hypotéz vycházíme $\mathrm{z}$ faktu, který je uváděn i v četných odborných teoretických statích, že konstituování a transformace pojmu technická gramotnost do vzdělávacího a didaktického systému je záležitostí poměrně novou (1). Na základě tohoto faktického stavu předpokládáme, že současní studenti budou disponovat jiným, aktuálnějším pojetím pojmu technická gramotnost, než jejich starší kolegové, učitelé již delší dobu v činné praxi na 1. stupni Z 


\section{Výzkumný vzorek}

Výzkum proběhl v letech 2010-2011 a výzkumný vzorek tvořilo 113 studentů 3. (tehdy předposledního) ročníku studia oboru Učitelství pro 1 . stupeň ZŠ. Z celkového počtu byla převážná část dívek (90 \%). Výzkum se uskutečnil na Pedagogické fakultě JU v Českých Budějovicích $\mathrm{v}$ předmětu Didaktika technické výchovy. Návratnost dotazníku byla $78 \%$.

Druhý výzkumný vzorek tvořilo 68 učitelů z prvního stupně základních škol z Jihočeského a Středočeského kraje. Jednalo se pouze o učitelky, různé věkové kategorie, rozmezí 28- 55 let. Návratnost dotazníku byla $66 \%$.

\section{Testování platnosti hypotéz}

$\mathbf{H}_{1}$ - U vnímání pojmu technická gramotnost je mezi učiteli na 1 . stupni $Z \breve{S}$ a studenty pedagogické fakulty významný rozdíl.

Nejprve jsme formulovali nulovou a alternativní hypotézu $\mathrm{k}$ hypotéze $\mathrm{H}_{1}$

Nulová hypotéza: U vnímání pojmu technická gramotnost není mezi učiteli na 1. stupni ZŠ a studenty pedagogické fakulty významný rozdíl.

Alternativní hypotéza: U vnímání pojmu technická gramotnost je mezi učiteli na 1. stupni ZŠ a studenty pedagogické fakulty významný rozdíl.

Pro testování platnosti hypotézy bylo použito nestandardizovaného U-testu Manna a Whitneyho a pomocí statistického programu STATISTICA 9 byly vypočítány signifikance $p$, kterou uvádí tabulka 1. Pro testování byla zvolena hladina významnosti $\mathrm{p}=0,05$.

Na základě vypočítaných hodnot signifikance $(\mathrm{p}=0,64 ; 0,83 ; 067 ; 0,63 ; 0,82 ; 0,66) \quad$ lze konstatovat, že na hladině významnosti $p=0,05$ odmítáme alternativní hypotézu a přijímáme hypotézu nulovou.

Konstatování: U vnímání pojmu technická gramotnost není mezi učiteli na 1 . stupni ZŠ a studenty pedagogické fakulty významný rozdíl. Nebyla tedy potvrzena platnost výchozí hypotézy $\mathrm{H}_{1}$

Závěr: Skupina studentů vnímá pojem technická gramotnost významně podobně jako skupina učitelů z praxe na 1 . stupni Z $\breve{S}$.

Testování platnosti hypotézy $\mathrm{H}_{2}$

$\mathbf{H}_{2}$ U vnímání pojmu technická gramotnost je ve faktoru hodnocení rozdíl mezi učiteli na 1. stupni ZŠ a studenty pedagogické fakulty.

Nejprve jsme formulovali nulovou a alternativní hypotézu k hypotéze $\mathrm{H}_{2}$
Nulová hypotéza: U vnímání pojmu technická gramotnost není ve faktoru hodnocení rozdíl mezi učiteli na 1 . stupni $Z \breve{S}$ a studenty pedagogické fakulty.

Alternativní hypotéza: U vnímání pojmu technická gramotnost je ve faktoru hodnocení rozdíl mezi učiteli na 1 . stupni $Z \breve{S}$ a studenty pedagogické fakulty.

Pro testování platnosti hypotézy bylo použito nestandardizovaného U-testu Manna a Whitneyho a pomocí statistického programu STATISTICA 9 byly vypočítány signifikance $\mathrm{p}$, které uvádí tabulka 2. Pro testování byla zvolena hladina významnosti $\mathrm{p}=0,05$.

Na základě vypočítaných hodnot signifikance $(\mathrm{p}=0,67 ; 0,66)$ lze konstatovat, že na hladině významnosti $\mathrm{p}=0,05$ odmítáme hypotézu alternativní

Konstatování: U vnímání pojmu technická gramotnost není ve faktoru hodnocení rozdíl mezi učiteli na 1 . stupni Z $Z$ S a studenty pedagogické fakulty. Nebyla tedy potvrzena platnost výchozí hypotézy $\mathrm{H}_{2}$

Závěr: Skupina studentů vnímá pojem technická gramotnost ve faktoru hodnocení podobně jako skupina učitelů $\mathrm{z}$ praxe na 1 . stupni ZŠ.

\section{Testování platnosti hypotézy $\mathrm{H}_{3}$}

$\mathbf{H}_{3} \mathrm{U}$ vnímání pojmu technická gramotnost je ve faktoru aktivity rozdíl mezi učiteli na 1 . stupni ZŠ a studenty pedagogické fakulty.

Nejprve jsme formulovali nulovou a alternativní hypotézu $\mathrm{k}$ hypotéze $\mathrm{H}_{3}$

Nulová hypotéza: U vnímání pojmu technická gramotnost není ve faktoru aktivity rozdíl mezi učiteli na 1 . stupni ZŠ a studenty pedagogické fakulty.

Alternativní hypotéza: U vnímání pojmu technická gramotnost je ve faktoru aktivity rozdíl mezi učiteli na 1 . stupni ZŠ a studenty pedagogické fakulty.

Pro testování platnosti hypotézy bylo použito nestandardizovaného U-testu Manna a Whitneyho a pomocí statistického programu STATISTICA 9 byly vypočítány signifikance $p$, které uvádí tabulka 3. Pro testování byla zvolena hladina významnosti $\mathrm{p}=0,05$.

$\mathrm{Na}$ základě vypočítaných hodnot signifikance $(\mathrm{p}=0,44 ; 0,43)$ lze konstatovat, že na hladině významnosti $\mathrm{p}=0,05$ odmítáme alternativní hypotézu a přijímáme hypotézu nulovou.

Konstatování: U vnímání pojmu technická gramotnost není ve faktoru aktivity rozdíl mezi učiteli na 1. stupni ZŠ a studenty pedagogické 
fakulty. Nebyla tedy potvrzena platnost výchozí hypotézy $\mathrm{H}_{3}$

Závěr: Skupina studentů vnímá pojem technická gramotnost ve faktoru aktivity podobně jako skupina učitelů z praxe na 1. stupni ZŠ.

\section{Testování platnosti hypotézy $\mathbf{H}_{4}$}

$\mathbf{H}_{4} \mathrm{U}$ vnímání pojmu technická gramotnost je ve faktoru potence rozdíl mezi učiteli na 1 . stupni ZŠ a studenty pedagogické fakulty.

Nejprve jsme formulovali nulovou a alternativní hypotézu k hypotéze $\mathrm{H}_{4}$

Nulová hypotéza: U vnímání pojmu technická gramotnost není ve faktoru potence rozdíl mezi učiteli na 1 . stupni $Z S \mathrm{~S}^{2}$ a studenty pedagogické fakulty.

Alternativní hypotéza: U vnímání pojmu technická gramotnost je ve faktoru potence rozdíl mezi učiteli na 1 . stupni $Z \check{S}$ a studenty pedagogické fakulty.
Pro testování platnosti hypotézy bylo použito nestandardizovaného U-testu Manna a Whitneyho a pomocí statistického programu STATISTICA 9 byly vypočítány signifikance $p$, které uvádí tabulka 4 . Pro testování byla zvolena hladina významnosti $\mathrm{p}=0,05$.

$\mathrm{Na}$ základě vypočítané hodnoty signifikance $(\mathrm{p}=0,84 ; 0,84)$ lze konstatovat, že na hladině významnosti $\mathrm{p}=0,05$ odmítáme alternativní hypotézu a přijímáme hypotézu nulovou.

Konstatování: U vnímání pojmu technická gramotnost není ve faktoru potence rozdíl mezi učiteli na 1. stupni ZŠ a studenty pedagogické fakulty. $\mathrm{H}_{4}$

Nebyla potvrzena platnost výchozí hypotézy

Závěr: Skupina studentů vnímá pojem technická gramotnost ve faktoru potence podobně jako skupina učitelů z praxe na 1 . stupni ŽS.

Tabulka 1: Výpočet signifikancí pro testování platnosti hypotézy $H_{l}$

\begin{tabular}{|l|l|l|c|c|c|c|c|r|r|}
\hline \multirow{2}{*}{} & \multicolumn{9}{|l|}{$\begin{array}{l}\text { Mann-Whitneyův U test (List v Technická gramotnost.s tw (C3:PS435)) } \\
\text { Dle proměn. TG učitelé } \\
\text { Označené testy jsou významné na hladině } p<, 05000\end{array}$} \\
\cline { 2 - 10 } & $\begin{array}{c}\text { Sčt poř. } \\
\text { Proměnná }\end{array}$ & $\begin{array}{c}\text { Sčt poř. } \\
2\end{array}$ & $\mathrm{U}$ & $\mathrm{Z}$ & p-hodn. & $\begin{array}{c}\text { Z } \\
\text { upravené }\end{array}$ & p-hodn. & $\begin{array}{c}\text { N platn. } \\
4\end{array}$ & $\begin{array}{c}\text { N platn. } \\
2\end{array}$ \\
\hline hodnocení S & 12045,50 & 10959,50 & 5490,500 & $-0,462451$ & 0,643759 & $-0,477812$ & 0,632784 & 114 & 100 \\
\hline potence S & 6987,00 & 6379,00 & 3246,000 & $-0,214404$ & 0,830232 & $-0,221465$ & 0,824730 & 86 & 77 \\
\hline aktivita S & 6926,00 & 6440,00 & 3185,000 & $-0,417175$ & 0,676551 & $-0,433479$ & 0,664667 & 86 & 77 \\
\hline
\end{tabular}

Tabulka 2: Výpočet signifikancí pro testování platnosti hypotézy $\mathrm{H}_{2}$

\begin{tabular}{|c|c|c|c|c|c|c|c|c|c|}
\hline \multirow[b]{2}{*}{ Proměnná } & \multicolumn{9}{|c|}{$\begin{array}{l}\text { Mann-Whitneyův U test (List v Technická gramotnost.s tw (C3:PS435)) } \\
\text { Dle proměn. hodnocení } \\
\text { Oz načené testy jsou významné na hladině } p<, 05000\end{array}$} \\
\hline & $\begin{array}{l}\text { Sčt poř. } \\
\text { skup. } 1\end{array}$ & $\begin{array}{l}\text { Sčt poř. } \\
\text { skup. } 2\end{array}$ & $U$ & $\mathrm{Z}$ & p-hodn. & $\begin{array}{c}\mathrm{Z} \\
\text { upravené }\end{array}$ & p-hodn. & $\begin{array}{l}\text { N platn. } \\
\text { skup. } 1\end{array}$ & $\begin{array}{l}\text { N platn. } \\
\text { skup. } 2\end{array}$ \\
\hline hodnocení S & 2335,000 & 2816,000 & 1207,000 & $-0,418716$ & 0,675424 & $-0,430809$ & 0,666607 & 47 & 5 \\
\hline
\end{tabular}


Tabulka 3: Výpočet signifikancí pro testováni platnosti hypotézy $\mathrm{H}_{3}$

\begin{tabular}{|c|c|c|c|c|c|c|c|c|c|c|}
\hline \multirow[b]{2}{*}{ Proměnná } & \multicolumn{10}{|c|}{$\begin{array}{l}\text { Mann-Whitneyův U test (List v Technická gramotnost.stw (C3:PS435)) } \\
\text { Dle proměn. aktivita U } \\
\text { Označené testy jsou významné na hladině p <,05000 }\end{array}$} \\
\hline & $\begin{array}{l}\text { Sčt poř. } \\
\text { skup. } 1 \\
\end{array}$ & $\begin{array}{l}\text { Sčt poř. } \\
\text { skup. } 2\end{array}$ & U & $\mathrm{Z}$ & p-hodn. & $\begin{array}{c}\text { Z } \\
\text { upravené }\end{array}$ & p-hodn. & $\begin{array}{l}\mathrm{N} \text { platn. } \\
\text { skup. } 1\end{array}$ & $\begin{array}{l}\mathrm{N} \text { platn. } \\
\text { skup. } 2\end{array}$ & $\begin{array}{l}2^{*} 1 \text { str. } \\
\text { přesné p }\end{array}$ \\
\hline aktivita S & 1475,500 & 1225,500 & 595,5000 & 0,761900 & 0,446120 & 0,785966 & 0,431888 & 38 & 35 & 0,445125 \\
\hline
\end{tabular}

Tabulka 4: Výpočet signifikance pro testování platnosti hypotézy $\mathrm{H}_{4}$

\begin{tabular}{|c|c|c|c|c|c|c|c|c|c|c|}
\hline \multirow{3}{*}{ Proměnná } & \multicolumn{10}{|c|}{$\begin{array}{l}\text { Mann-Whitneyův U test (List v Technic ká gramotnost.stw (C3:PS435)) } \\
\text { Dle proměn. potence U } \\
\text { Označené testy jsou významné na hladině } p<, 05000\end{array}$} \\
\hline & \begin{tabular}{|l} 
Sčt poř. \\
skup. 1 \\
\end{tabular} & $\begin{array}{l}\text { Sčt poř. } \\
\text { skup. } 2\end{array}$ & $U$ & $Z$ & p-hodn. & $\begin{array}{c}\mathrm{Z} \\
\text { upravené }\end{array}$ & p-hodn. & $\begin{array}{l}\text { N platn. } \\
\text { skup. } 1\end{array}$ & $\begin{array}{l}\text { N platn. } \\
\text { skup. } 2\end{array}$ & $\begin{array}{l}2^{*} 1 \text { str. } \\
\text { přesné p }\end{array}$ \\
\hline & 2628,000 & 2322,000 & 1194,000 & 0,192696 & 0,847197 & 0,198458 & 0,842687 & 52 & 47 & 0,847881 \\
\hline
\end{tabular}

Tabulka 5: Průměrná hodnocení pro všechny faktory

\begin{tabular}{|c|c|c|c|}
\hline \multicolumn{4}{|c|}{ Technická gramotnost } \\
\hline & \multicolumn{3}{|c|}{ faktor } \\
\hline & hodnocení & potence & aktivity \\
\hline studenti & 2,81 & 3,02 & 3,07 \\
\hline učitelé & 3 & 3,02 & 2,88 \\
\hline
\end{tabular}

Graf 1: Průměrná hodnocení všech faktorů pro pojem technická gramotnost

\section{Průměrné hodnoty pro technickou gramotnost}

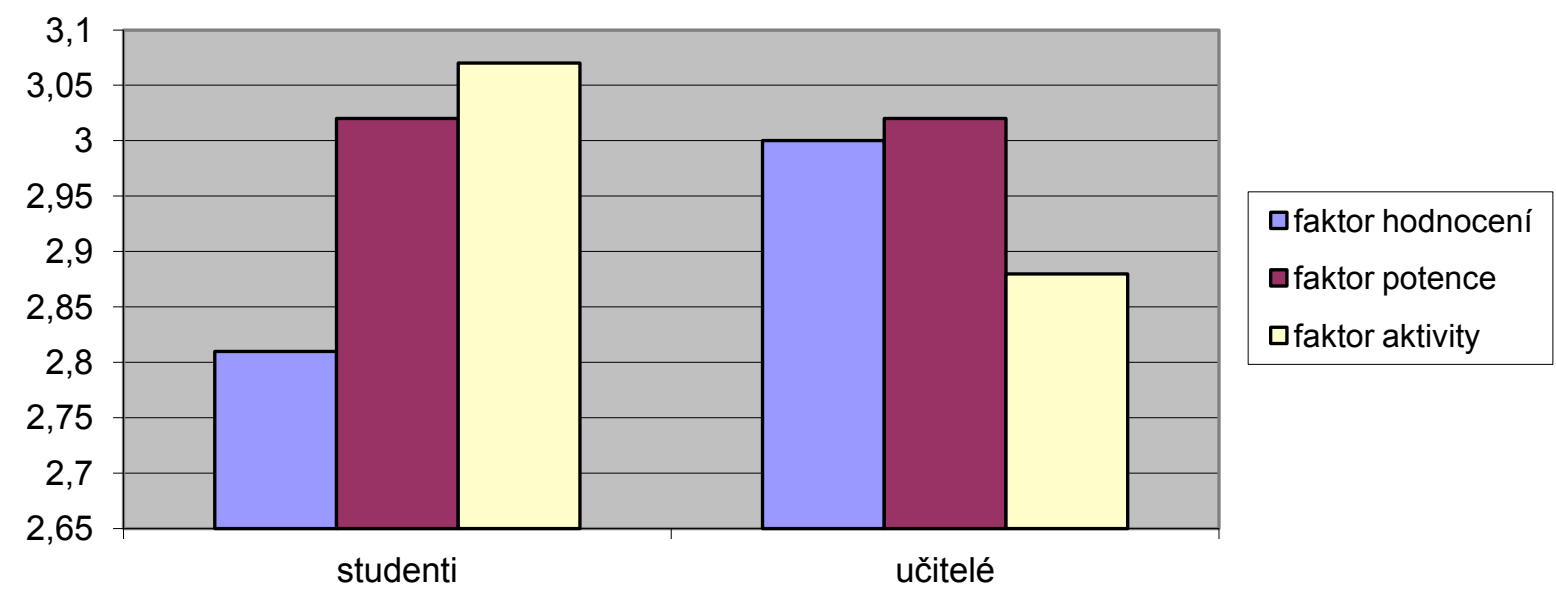

\section{A. Interpretace výsledků}

Pro vytvoření názorné představy o tom, jakým způsobem vnímají studenti pedagogické fakulty a učitelé 1. stupně ZŠ pojem technická gramotnost, byly spočítány průměrné hodnoty pro všechny faktory u obou skupin. Souhrnné výsledky obsahuje tabulka č. 5 a graf č. 1 .
Vzhledem $\mathrm{k}$ faktu, že byla použita pouze pětibodová škála sémantického diferenciálu, nepředstavují průměrná hodnocení všech faktorů, pohybující se nejčastěji kolem hodnoty 3, nikterak optimální obraz o individuální podobě vnímání pojmu technická gramotnost u respondentů výzkumu. 
Respondenti studenti významu, důležitosti technické gramotnosti přisuzují statisticky nevýznamně vyšší průměrné skóre, než učitelé z praxe. Ovšem spatřují technickou gramotnost maximálně průměrně důležitou, což je výsledek poněkud v rozporu se všeobecným zastoupením techniky v okolním světě a vysokými nároky na technickou gramotnost současné populace.

Průměrná podoba vnímání technické gramotnosti zhlediska vynaložené aktivity, energie, dosahuje lepších, nicméně statisticky nevýznamně rozdílných hodnot u skupiny učitelů. Respondenti učitelé předpokládají, že dosažení technické gramotnosti vyžaduje větši vynaloženou aktivitu, energii, než respondenti studenti.

V síle, potenci pojmu technická gramotnost dosahují obě skupiny shodných průměrných hodnot.

Na základě výsledků shlukové analýzy byly rozděleny základní charakteristiky vnímání pojmu technická gramotnost do následujících skupin, shluků. Výběr vychází z dat, obsažených $\mathrm{v}$ grafu č. 2 a 3.

Ve skupině studentů byly identifikovány 3 shluky:

\section{Shluk 1 (studenti)}

Do první skupiny se dají zahrnout ti studenti, jejichž vnímání pojmu technická gramotnost se vyznačuje vysokou úrovní hodnocení a průměrnou úrovní aktivity.

Tito respondenti se domnívají, že technická gramotnost je velmi důležitá a lze si ji osvojit průměrným vynaložením aktivity.

\section{Shluk 2 (studenti)}

Do druhé skupiny se dají zahrnout ti studenti, jejichž vnímání pojmu technická gramotnost se vyznačuje mírně podprůměrným skóre pro faktor hodnocení a vyšším než průměrným skóre pro výdej aktivity, energie. Tito respondenti se domnívají, že technická gramotnost je méně důležitá, ovšem její dosažení je spojeno s vyšší námahou, aktivitou.

\section{Shluk 3 (studenti)}

Do třetí skupiny se dají zahrnout ti studenti, jejichž vnímání pojmu technická gramotnost se vyznačuje mírně podprůměrným skóre pro faktor hodnocení, ve spojení s výrazně podprůměrným skóre pro výdej aktivity, energie. Tito respondenti technické gramotnosti přisuzují podprůměrnou důležitost a její dosažení pro ně představuje minimum vydané energie, aktivity.

Ve skupině učitelů byly identifikovány pouze 2 shluky.

\section{Shluk I (učitelé)}

Do první skupiny se dají zahrnout ti učitelé, jejichž vnímání pojmu technická gramotnost se vyznačuje vyšším skóre pro faktor hodnocení, spojený s prrisouzenou pouze průměrnou mírou aktivity. Tito respondenti technické gramotnosti přisuzují vyšší důležitost, ovšem její dosažení pro ně představuje pouze průměrnou aktivitu.

\section{Shluk II (učitelé)}

Do druhé skupiny se dají zahrnout ti učitelé, jejichž vnímání pojmu technická gramotnost se vyznačuje výrazně nízkým skóre pro faktor hodnocení spojený s průměrnou mírou aktivity, energie. Tito respondenti technickou gramotnost považují za výrazně méně důležitou a pro její získání předpokládají průměrnou energii, námahu. 
Graf 2: Výsledky shlukové analýzy pro skupinu studenti

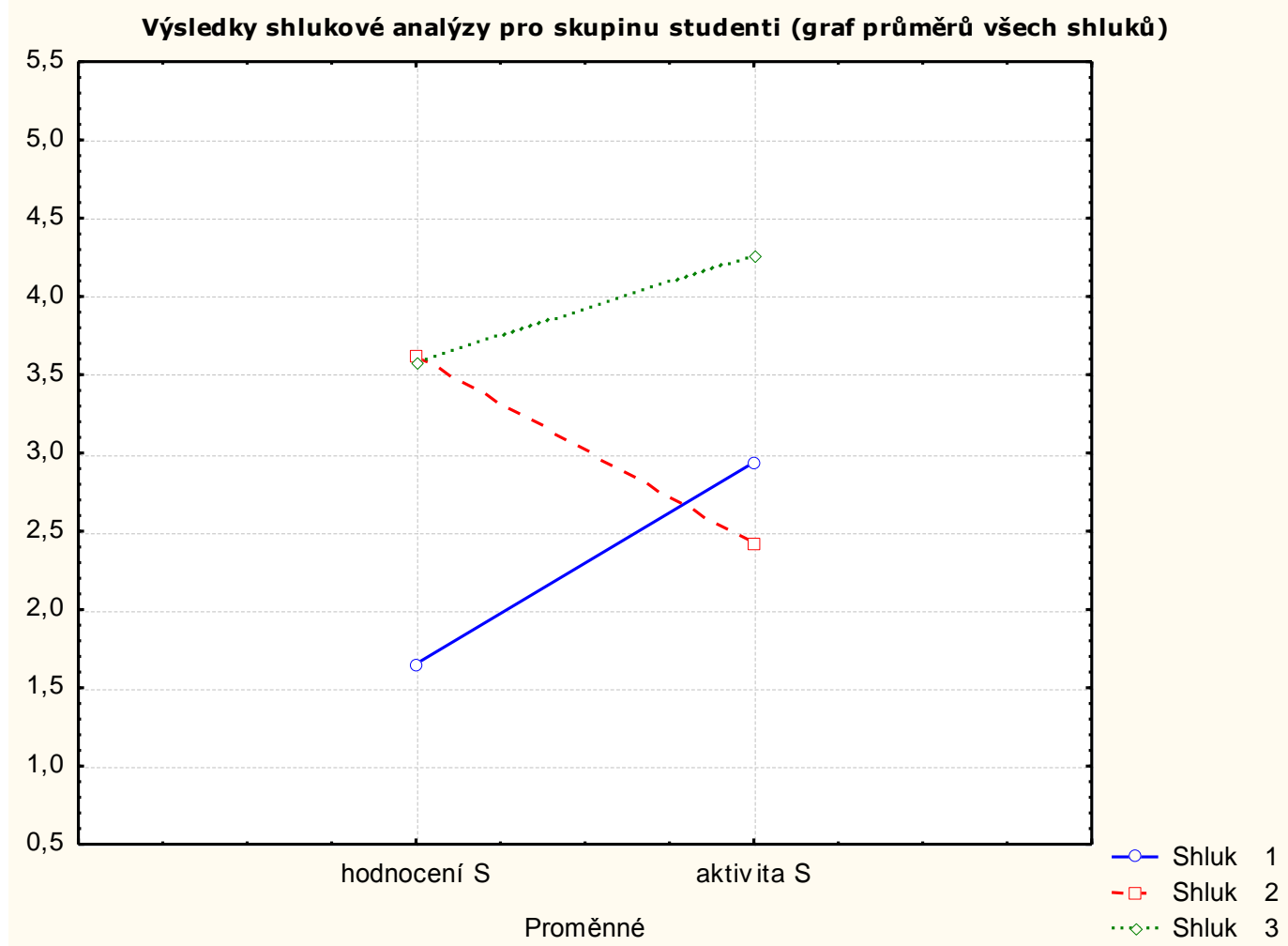

Graf 3: Výsledky shlukové analýzy pro skupinu učitelé

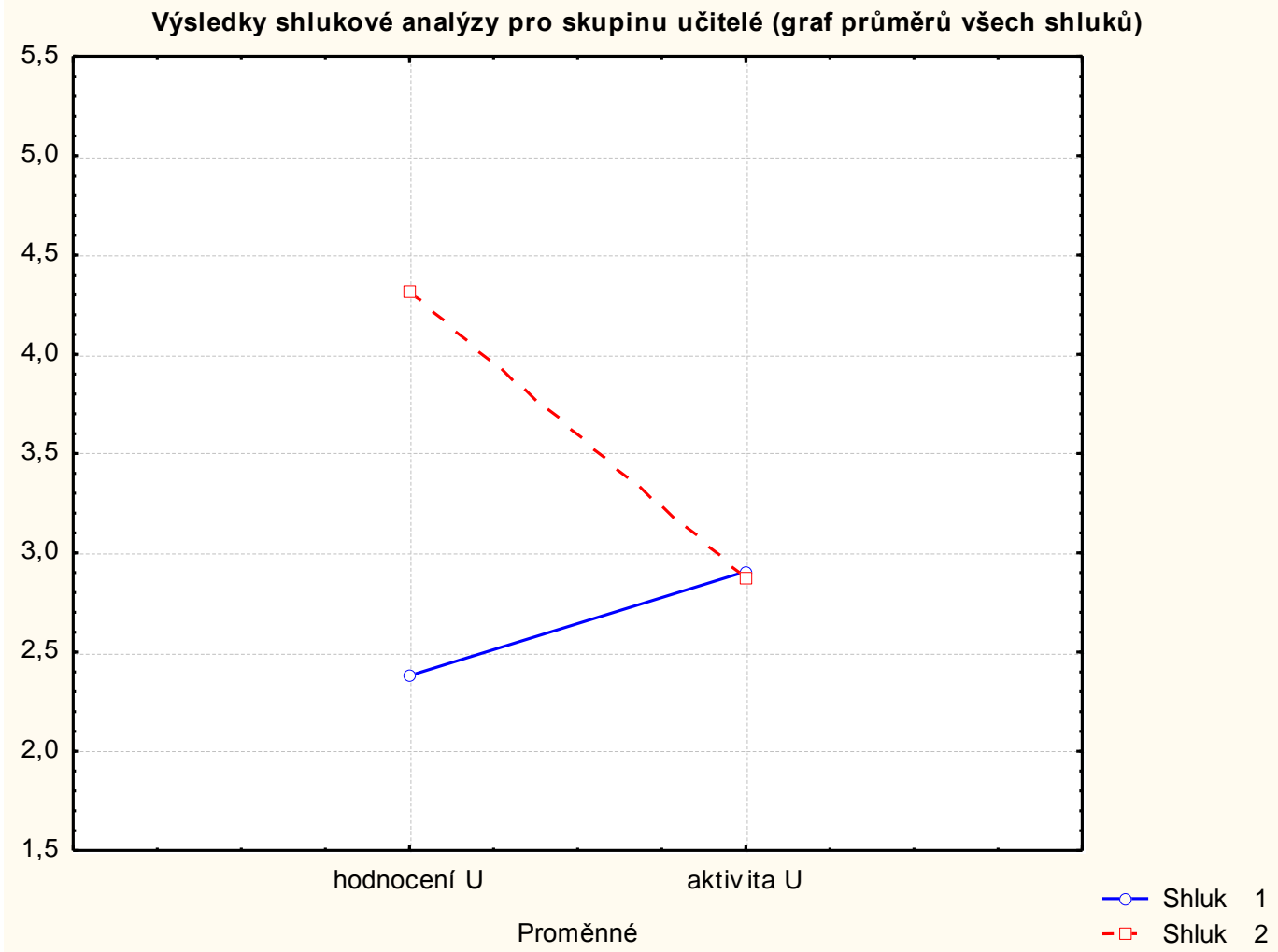




\section{Diskuse a závěry}

Při shrnutí výsledků orientačního výzkumu vycházíme především z jeho cílů a otázek, které jsme si kladli na jeho počátku. Na základě provedených analýz konstatujeme, že vnímání pojmu technická gramotnost je u obou skupin respondentů výzkumu podobné. Zjištěné rozdíly nebyly shledány statisticky významnými. Zajímavým zjištěním pro nás byl především fakt, že se nepotvrdilo, že by mladší generace studentů vnímala pojem technická gramotnost statisticky významně lépe jako důležitější, hodnotnější, aktivnější nebo mu přisuzovala větší potenci. Věk a praxe se neukázaly $v$ našem šetření jako významné pro představu o technické gramotnosti.

Podařilo se identifikovat některé základní typy charakteristik ve vnímání zkoumaného pojmu.

Technická gramotnost ve skupině studentů:

- je důležitá (ale pouze průměrně) a její získání představuje výdej průměrné míry aktivity;

- je méně, než průměrně důležitá a její získání představuje vyšší, než průměrnou aktivitu;

- má podprůměrnou důležitost a její dosažení je spojeno s minimem námahy.

Technická gramotnost ve skupině učitelů:

- má vyšší, ale pouze průměrnou důležitost a lze jí dosáhnout průměrnou aktivitou;

- je výrazně méně, než průměrně důležitá a lze jí dosáhnout průměrnou aktivitou.

Za mimořádně zajímavé považujeme zjištění, že čtyři z pěti zachycených typů charakteristik mají technickou gramotnost spojenu s malou vynaloženou aktivitou, úsilím. A ve všech skupinách dosahuje hodnocení důležitosti maximálně průměrných hodnot.

$Z$ výčtu zjištěných charakteristik lze usuzovat, že obě skupiny respondentů ve všech faktorech subjektivně pojem technická gramotnost celkově spíše podceňují. Je možné, že jedním z důvodů podceňování může být i jistá všeobecně menší míra znalosti a nesystémovost, která se ve vymezení technické gramotnosti v běžné i školské populaci objevuje a je $z$ důvodu poměrné novosti pojmu a jeho vymezení i částečně pochopitelná. Zároveň je ovšem ve velkém rozporu se zvyšujícími se nároky na technickou gramotnost současné populace. Aniž bychom se chtěli dopustit nemístné generalizace, musíme konstatovat, že podle našich mnohaletých zkušeností z výuky na primární škole a i podle výsledků tohoto výzkumu, se rozvoji technické gramotnosti věnuje, ve srovnání s ostatními druhy žákovských gramotností, mnohem menší pozornost a žáci jsou prri konstrukci technické gramotnosti do značné míry ponecháni individuální improvizaci. Zřejmě i především díky stále často rozšířenému výhradně psychomotorickému pojetí výuky předmětu Praktické činnosti na 1. stupni ZŠ, kdy kognitivní a afektivní složky nejsou ve výuce plnohodnotně zastoupeny (4).

Vzhledem k vysokému zastoupení žen ve výzkumném vzorku (95\%) nejsme schopni v této chvíli zodpovědět, zda má pohlaví člověka vliv na podobu subjektivního vnímání technické gramotnosti. Toto bude zohledněno $\mathrm{v}$ dalším výzkumu.

V príípadě zkoumaného pojmu technická gramotnost docházíme ke shodnému závěru jako Parkinson, E., (7, s. 2 ), který uvádí, že: „studenti učitelství si musí uvědomovat, že jejich případné miskoncepce, často z raného dětství, budou spolupůsobit při jejich budoucí výuce"(překlad Roučová, E. 2007 ).

V tomto konkrétním př́padě výzkumu se ukazuje, že subjektivní vnímání pojmu technická gramotnost u budoucích učitelů má mnohdy nerealistickou, zkreslenou a málo optimální podobu. A je pravděpodobné, že toto, mnohdy chybné, subjektivní pojetí, bude spolupůsobit při vytváření technické gramotnosti jejich budoucích žáků a může ji nežádoucím způsobem ovlivňovat i brzdit.

Pro pregraduální přípravu těchto studentů z výše uvedeného vyplývá, že bude nutno $\mathrm{v}$ předmětové didaktice používat takové strategie řízení učebních procesů studentů, které v prvé řadě povedou $\mathrm{k}$ žádoucí rekonstrukci výzkumně podchycených miskoncepcí v jejich subjektivním pojetí technické gramotnosti.

Pro učitele $\mathrm{z} 1$. stupně ZŠ vyplynuly z výzkumu zcela stejné závěry jako pro studenty. Možnosti pro rekonstrukci nevhodných subjektivních pojetí technické gramotnosti spatřujeme jako prakticky komplikované.

V současné době ve výzkumu subjektivního pojetí různých odborných pojmů z oblasti techniky, včetně zde prezentované technické gramotnosti, dále pokračujeme. Naším cílem je poskytnout odborné veřejnosti komplexnější a relevantní výsledky.

\section{Literatura}

[1] KROPÁČ, J., KUBÍČEK, Z., CHRÁSKA, M., HAVELKA, M. Didaktika technických predmětů: vybrané kapitoly. 1. vyd. Olomouc: 
Univerzita Palackého, 2004. 223 s. ISBN 80-2440848-1.

[2] ALMÄKI, A. Technology Education in the Finnish Primary Schools. In Journal of Technology Education. 1999, Vol. 11, N. 1. ISSN 1045-1064. [cit. 2006-01-22]. Dostupné na: http://scholar.lib.vt.edu/ejournals/JTE/v11n1/pdf/ almaki.pdf

[3] KROPÁČ, J., HAVELKA, M. Poznámky k pojmu „technické myšleni". [cit. 2005-04-22] Dostupné na: http://www. kteiv.upol.cz

[4] ROUČOVÁ, E. Prekoncepty $k$ didaktice technické výchovy u studentů učitelství pro primárni školu. Olomouc: PdF UP, 2007. 194 s. Nepublikovaná disertační práce.

[5] CHRÁSKA, M. Úvod do výzkumu v pedagogice. 1. vyd. Olomouc: Univerzita Palackého, 2003. 199 s. ISBN 80-244-0765-5.

[6] ROUČOVÁ, E. Diagnostika studentova pojetí učiva o technice a didaktice. In Svět výchovy a vzdèlávání v reflexi současného pedagogického výzkumu. XV. Konference České asociace pedagogického výzkumu. České Budějovice: PdF JU, 2007. Sborník abstrakt s. 99. Sborník př́spěvků: CD-ROM. ISBN 978-80-7040-987-9.

[7] PARKINSON, E. Teacher Knowledge and Understanding of Design and Technology for Children in the 3-11 Age Group: A Study Focusing on Aspects of Structures. In Journal of Technology Education. 2001, Vol. 13, N. 1. ISSN 1045-1064. [cit. 2006-01-12]. Dostupné na: http://scholar.lib.vt.edu/ejournals/JTE/v13n1/pdf/ parkinson.pdf

PhDr. Eva Roučová, Ph.D.

Katedra aplikované fyziky a techniky

Pedagogická fakulta Jihočeské univerzity

Jeronýmova 10

371 15, České Budějovice, ČR

Tel: +420 387773100

E-mail: evro@pf.jcu.cz

Www pracoviště:

www.pf.jcu.cz/stru/katedry/fyz/ 